\title{
A 1200 Year Record of Hydrologic Variability in the Sierra Nevada from Sediments in Walker Lake, Nevada
}

\author{
Fasong Yuan \\ Cleveland State University, f.yuan06@csuohio.edu \\ Braddock K. Linsley \\ University at Albany-State University of New York \\ Steve P. Lund \\ University of Southern California \\ John P. McGeehin \\ U.S. Geological Survey
}

Follow this and additional works at: https://engagedscholarship.csuohio.edu/scibges_facpub

Part of the Biology Commons

How does access to this work benefit you? Let us know!

Publisher's Statement

Copyright 2004 by the American Geophysical Union 10.1029/2003GC000652

\section{Recommended Citation}

Yuan, F., B. K. Linsley, S. P. Lund, and J. P. McGeehin (2004), A 1200 year record of hydrologic variability in the Sierra Nevada from sediments in Walker Lake, Nevada, Geochem. Geophys. Geosyst., 5(3), Q03007, doi:10.1029/2003GC000652.

This Article is brought to you for free and open access by the Biological, Geological, and Environmental Sciences Department at EngagedScholarship@CSU. It has been accepted for inclusion in Biological, Geological, and Environmental Faculty Publications by an authorized administrator of EngagedScholarship@CSU. For more information, please contact library.es@csuohio.edu. 


\title{
A 1200 year record of hydrologic variability in the Sierra Nevada from sediments in Walker Lake, Nevada
}

\author{
Fasong Yuan \\ Department of Earth and Atmospheric Sciences, University at Albany-State University of New York, 1400 \\ Washington Avenue, Albany, New York 12222, USA
}

Now at Texas AEM University Agriculture Research and Extension Center, 1380 A EM Circle, El Paso, Texas 79927, USA (fyuan@tamu.edu)

Braddock K. Linsley

Department of Earth and Atmospheric Sciences, University at Albany-State University of New York, 1400

Washington Avenue, Albany, New York 12222, USA (blinsley@albany.edu)

\section{Steve P. Lund}

Department of Earth Sciences, University of Southern California, Los Angeles,

California 90089, USA (slund@usc.edu)

\section{John P. McGeehin}

U.S. Geological Survey, 12201 Sunrise Valley, Reston, Virginia 20192, USA (mcgeehin@usgs.gov)

[1] Measurements of the oxygen isotopic composition $\left(\delta^{18} \mathrm{O}\right)$ of the total inorganic carbon (TIC) fraction from cored sediments of Walker Lake, Nevada, were conducted at an average resolution of $\sim 3$ years per sample over the last 1200 years. On the basis of radiocarbon analysis on the total organic carbon (TOC) fraction, a $\delta^{18} \mathrm{O}$ time series was created to reconstruct changes in hydrologic conditions back to AD 800 . The timings of variations in the TIC $\delta^{18} \mathrm{O}$ record are generally consistent with the tree ring-based Sacramento River flow record spanning AD 869 to 1977, indicating that Walker Lake $\delta^{18} \mathrm{O}$ contains information about past changes in at least regional hydrologic conditions. Comparison with the $\delta^{18} \mathrm{O}$ record from Pyramid Lake sediments indicates that both basins have recorded five century-scale oscillations in regional hydrologic conditions since AD 800. Several of these changes in hydrologic conditions appear synchronous with century-scale California Current water temperature changes derived from analysis of sediment cores from the Santa Barbara Basin also attesting to the regional extent of these climatic fluctuations. Nearly synchronous oscillations in the Sierra wetness and the California Current suggest that regional changes in atmospheric circulation may have played an important role in century-scale climate variability over the last millennium.

Components: 5758 words, 8 figures, 2 tables.

Keywords: Walker Lake; oxygen isotopes; lake sediments; hydrologic variability; last millennium; Sierra Nevada.

Index Terms: 1040 Geochemistry: Isotopic composition/chemistry; 1719 History of Geophysics: Hydrology; 3344 Meteorology and Atmospheric Dynamics: Paleoclimatology..

Received 23 October 2003; Revised 22 January 2004; Accepted 24 February 2004; Published 25 March 2004.

Yuan, F., B. K. Linsley, S. P. Lund, and J. P. McGeehin (2004), A 1200 year record of hydrologic variability in the Sierra Nevada from sediments in Walker Lake, Nevada, Geochem. Geophys. Geosyst., 5, Q03007, doi:10.1029/2003GC000652. 


\section{Introduction}

[2] Climatic variations over the last millennium has received mounting attention in recent studies [Crowley, 2000; Jones et al., 2001; Cobb et al., 2003]. In broad terms, the climate of the last millennium is characterized by century-scale changes in mean temperature; the Medieval Warm Epoch (MWE) (AD 900-1350), followed by the Little Ice Age (LIA) (AD 1350-1850) and then a globally extensive warming [Bradley, 2000]. In spite of advances in understanding the response of the Sierra Nevada region to these century-scale climatic "events" [Scuderi, 1993; Stine, 1994; Hughes and Graumlich, 1996; Meko et al., 2001; Benson et al., 2002], the climatic dynamics and hydrologic fluctuations in the region are not well understood.

[3] In the western United States, climate-related droughts have severe societal impacts due to the dependence of the agriculture industry on limited water resources. As observed, a decadal to interdecadal reoccurring pattern of droughts that occurred over the last century has created considerable interest in understanding how the climate in this region evolves and can lead to such costly droughts as the "Dust Bowl" of 1928-1934 and the severe drought of 1987 to 1992. Analysis of instrumental climate variables in the western United States suggests that the northern Sierra lies on a correlation hinge point with respect to the El Niño/Southern Oscillation (ENSO) system [Redmond and Koch, 1991]. More recently, paleoclimate studies suggest that Sierra aridity has been linked with the multidecadal changes in the Pacific climate system at least over the last 300 years [Benson et al., 2003]. Specifically, Benson et al. [2003] observed that the interdecadal ( $60-80$ years) reoccurring droughts in the Mono Lake basin and in a Northern Sierra tree ring based index occurred during Pacific Decadal Oscillation (PDO) maxima. However, detailed examination on the relationship between the PDO index and the discharge of West Walker River (WWR) in Nevada presents a more complex picture, in which the WWR discharge maxima tend to be positively correlated with the PDO index when PDO is in warm/positive phase, and vice versa [Yuan, 2003]. There is a clear need to extend the existing climate record and develop a more thorough understanding of the climate conditions in the region that result in western U.S. droughts and also of past drought recurrence intervals.

[4] Here we present a sediment record from Walker Lake, Nevada spanning the last 1200 years that displays large decadal to century-scale variations in the $\delta^{18} \mathrm{O}$ of the total inorganic carbon (TIC) fraction. We compare these results with other published climatic indices to develop a regional context for the observed century-scale hydrologic variability.

\section{Walker Lake Basin}

[5] Walker Lake $\left(38^{\circ} 42^{\prime} \mathrm{N}, 118^{\circ} 43^{\prime} \mathrm{W}\right)$, a hydrologically closed basin, is situated in the western margin of the Great Basin of the western United States (Figure 1a). The primary water source is from the Walker River that is fed by snowmelt in the Sierra Nevada and water loss from the lake is mainly through evaporation. The hydrologic balance of the lake is maintained by evaporation and runoff of Sierran snowmelt. Sierra precipitation is primarily affected by the wintertime position of the polar jet stream [Ware and Thomson, 2000].

[6] In the Walker Lake basin, there are three types of surface waters with distinct $\delta^{18} \mathrm{O}$ signatures (Table 1). The $\delta^{18} \mathrm{O}$ of Walker Lake water $\left(\delta^{18} \mathrm{O}_{\mathrm{L}}\right)$ is primarily determined by its water balance. When the amount of stream inflow exceeds that of evaporation, the lake level rises and lake water becomes ${ }^{18} \mathrm{O}$-depleted, and vice versa. Although changes in water temperature may influence the $\delta^{18} \mathrm{O}$ of lacustrine inorganic carbonates, the magnitude of temperature-induced $\delta^{18} \mathrm{O}$ variations in this lake is believed to be relatively small compared to that of hydrologically induced $\delta^{18} \mathrm{O}$ variations. This is because most of inorganic $\mathrm{CaCO}_{3}$ precipitates at a temperature of $\sim 22^{\circ} \mathrm{C}$ [Benson et al., 1991]. Thus the $\delta^{18} \mathrm{O}$ changes in downcore bulk inorganic carbonates from Walker Lake are interpreted to primarily reflect changes in lake hydrologic balance. Annual discharge of rivers with headwaters in the Sierra Nevada are highly 

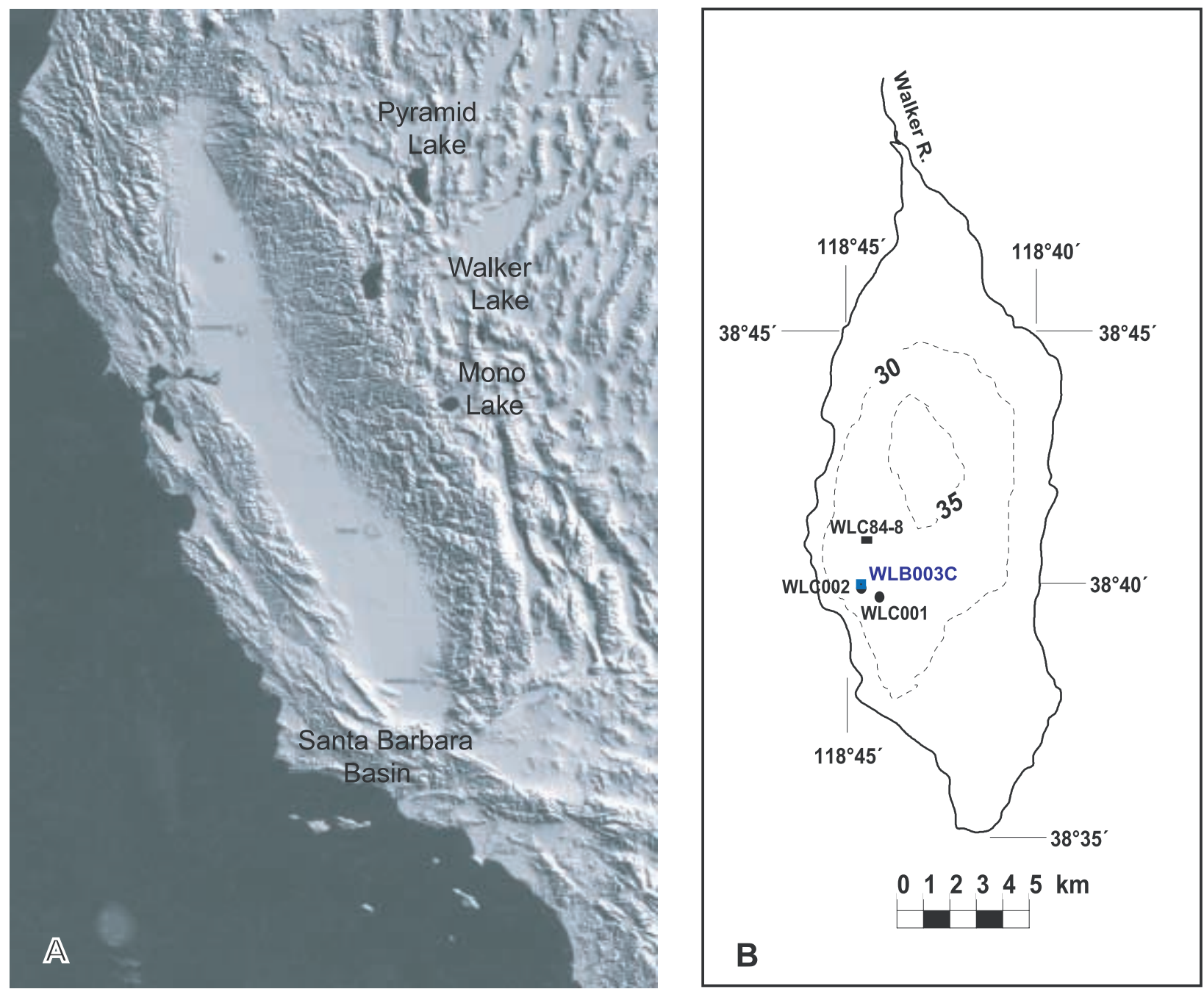

Figure 1. (a) Shaded relief map showing locations of Walker Lake, Pyramid Lake, Mono Lake, and Santa Barbara Basin (original map data from USGS). (b) Bathymetry and sediment core sites in Walker Lake (bathymetric map was modified after Benson [1988]).

correlated [Benson et al., 2002] and hydrologic simulations suggest that without anthropogenic perturbations there would be synchronous changes in the elevations of the lakes along the western margin of the Great Basin [Milne and Benson, 1987]. Thus $\delta^{18} \mathrm{O}$ records preserved in carbonates in downcore sediments from Walker Lake have the potential of recording past variations in Sierra Nevada relative aridity with a regional climatic significance.

\section{Methods}

[7] Two piston cores (WLC001 and WLC002) plus one boxcore (WLB-003C) were collected from the western side of Walker Lake in $\sim 30 \mathrm{~m}$ of water in June 2000 (Figure 1b). Core WLC001 is $5.6 \mathrm{~m}$ in length and core WLC002 is $\sim 4.8 \mathrm{~m}$. There was a loss of about $8-10 \mathrm{~cm}$ at the bottom of the uppermost section of WLC002 during core recovery. Piston cores were split, described, and one half of the core was slab sampled at 1-cm intervals. The boxcore was extruded vertically and sampled every $0.5 \mathrm{~cm}$. Samples were washed in deionized water, oven dried, and homogenized prior to coulometric and isotopic analyses [Yuan, 2003]. Percent TIC was measured on bulk samples using a coulometer and the $\delta^{18} \mathrm{O}$ of TIC measured using a Micromass Optima gas-source mass spectrometer with a MultiPrep automated sample preparation device. 
Table 1. Surface Waters and Their Oxygen Isotopic Ratios $^{\mathrm{a}}$

\begin{tabular}{ccccc}
\hline $\begin{array}{c}\text { Surface } \\
\text { Water }\end{array}$ & $\begin{array}{c}\text { Stream } \\
\text { Flow }\end{array}$ & Rainfall & $\begin{array}{c}\text { Water } \\
\text { Vapor }\end{array}$ & $\begin{array}{c}\text { Lake } \\
\text { Water }\end{array}$ \\
\hline $\begin{array}{c}\text { Quantity, km } \\
\delta^{18} \mathrm{O}, \% \text { o }\end{array}$ & 0.155 & 0.019 & 0.188 & 2.67 \\
\hline
\end{tabular}

${ }^{\mathrm{a}}$ The $\delta^{18} \mathrm{O}$ values of stream flow, rainfall, and lake waters were determined through measurements of water samples collected during the period of 1985-1994 [Benson et al., 1996], and the $\delta^{18} \mathrm{O}$ value of evaporated water was estimated through Benson and White's [1994] equation.

The isotopic results are reported relative to Vienna Peedee Belemnite (VPDB) standard, based on working standards calibrated against NBS-19. The overall precision for standard materials was $0.04 \%$ for $\delta^{18} \mathrm{O}$ and $0.1 \%$ for TIC, and the mean relative error of replicates is $1.7 \%(n=59)$ for $\delta^{18} \mathrm{O}$ and $<2.0 \%$ for TIC.

\section{Age Control}

[8] The chronology of cores WLC001 and WLC002 is based on 1) radiocarbon analysis of the organic carbon fraction, 2) correlation of rapid changes in downcore $\delta^{18} \mathrm{O}$ to instrumentally observed lake level fluctuations, and 3) other chemical tracers of historical events like mercury input from mining activities. Direct comparison of $\delta^{18} \mathrm{O}$ results from the boxcore with uppermost $0.7 \mathrm{~m}$ of $\delta^{18} \mathrm{O}$ data indicates a trivial loss $(<5 \mathrm{~cm})$ at the top of the piston cores (Figures $2 \mathrm{~b}$ and $2 \mathrm{c}$ ). The sediments sampled at $40 \mathrm{~cm}$ with an uncorrected ${ }^{14} \mathrm{C}$ age of $345 \pm 35 \mathrm{yr}$ B. P. (CAMS 87139) are $10 \mathrm{~cm}$ below the depth $(\sim 30 \mathrm{~cm})$ with a marked $\delta^{18} \mathrm{O}$ transition (Figure 2b). A Hg record derived from another piston core taken from a deeper section of Walker Lake, indicates that $\mathrm{Hg}$ started to move above background levels at approximately $54 \mathrm{~cm}$ in WLC002 and return to background at approximately $38 \mathrm{~cm}$ (M. Lico, unpublished data, 2002). Mining activities of the Comstock Lode began in 1859 and was well under way in 1860 s with $\mathrm{Hg}$ amalgamation processes in the region. The production of the Comstock mines was substantially reduced in 1899 [Smith, 1943]. Thus the calendar age of the sample at $40 \mathrm{~cm}(345 \pm 35 \mathrm{yr} \mathrm{B}$. P. $)$ is close to AD 1900 (Figures 2a and 2b). A 310-yr reservoir correction is needed for ${ }^{14} \mathrm{C}$ age calibration and this reservoir correction is in line with a 300-yr reservoir effect resulting from the Broecker and Walton [1959] carbon balance model. Radiocarbon ages were calibrated to calendar years through the Stuiver et al. [1998] method (Table 2). Calibrated radiocarbon ages were plotted versus depth in Figure 3. For the discussion in this paper, the bottom $0.8 \mathrm{~m}$ of data are not used here because of relatively low accumulation rates and potential that the TIC has been recrystallized [Spencer, 1977; Benson et al., 1991]. The bulk inorganic
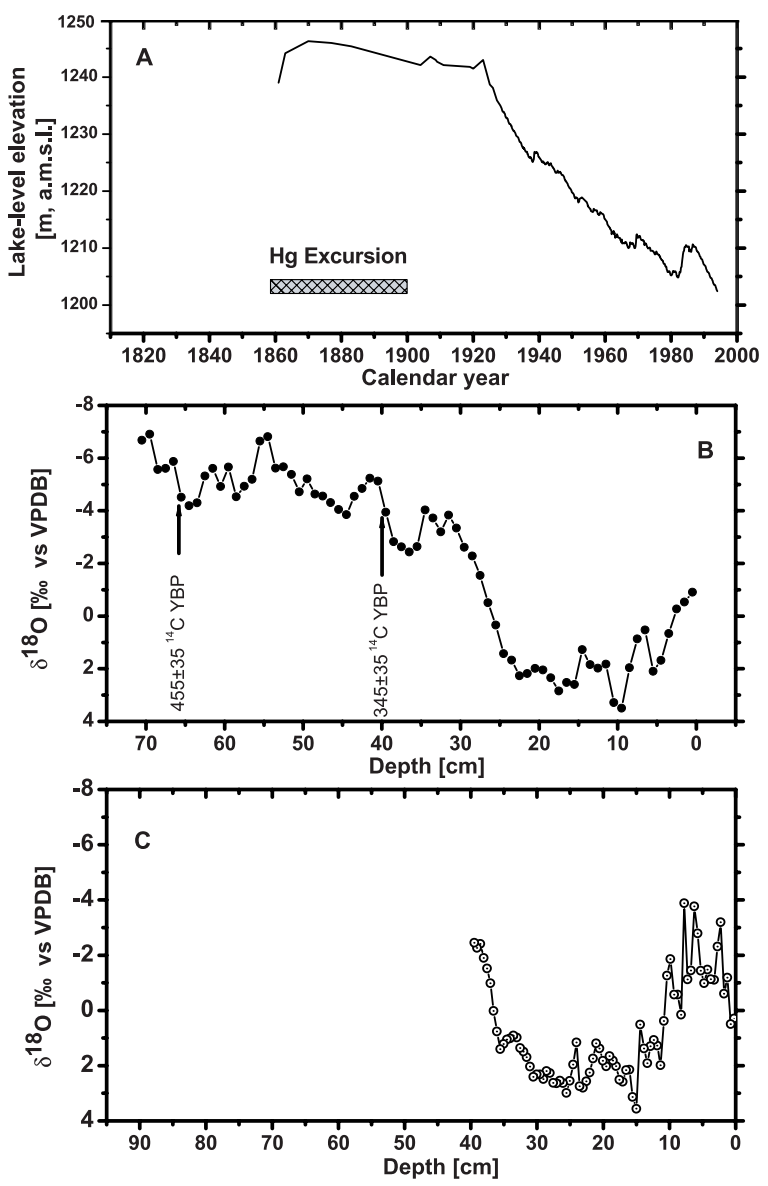

Figure 2. (a) Instrumental-based lake level record of Walker Lake measured by U.S. Geological Survey. Hg Excursion designates the period of 1860 through 1900 when $\mathrm{Hg}$ concentrations were above background levels due to both smelting and $\mathrm{Hg}$ amalgamation processes in this region [Smith, 1943]. (b) Topmost $70 \mathrm{~cm} \delta^{18} \mathrm{O}$ data of core WLC002. Solid arrows indicate positions of two uncorrected radiocarbon dates. (c) Results of $\delta^{18} \mathrm{O}$ measurements from box core WLB-003C with $0.5-\mathrm{cm}$ sample spacing. 


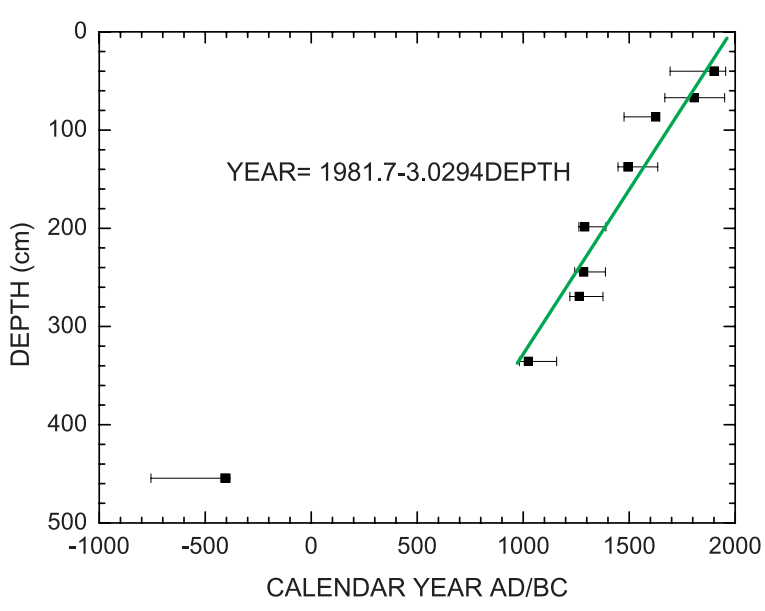

Figure 3. Plot of calibrated radiocarbon ages versus depth for core WLC002. Calendar ages were calibrated through the Stuiver et al. [1998] method and a 310-yr reservoir correction was used. Individual error bar was marked according to $2-\sigma$ range in Table 2 . Linear age model was derived on the basis of the upper eight dates.

carbonate $\delta^{18} \mathrm{O}$ record spans the last 1200 years with an average resolution of $\sim 3$ years per sample.

\section{Core Continuity and Reproducibility of the $\delta^{18} \mathrm{O}$ Record}

[9] The stratigraphy of core WLC001 is highly correlated with core WLC002 on the basis of lithology and downcore magnetic susceptibility (Figure 4). Ages depicted in Figure 4 are uncorrected radiocarbon dates of the TOC fraction from both cores WLC001 and WLC002. 50 samples in the interval from 35 to $85 \mathrm{~cm}$ in core WLC001 were taken to splice across the gap in core WLC002 (Figures 4 and 5a). Most of $\delta^{18} \mathrm{O}$ data points from WLC001 overlap with those from WLC002. Moreover, the spliced $\delta^{18} \mathrm{O}$ record is consistent with a $\delta^{18} \mathrm{O}$ record derived from a previously analyzed core (WLC84-8 [Benson et al., 1991; Yuan, 2003]) (Figures 5a and 5b). The temporal resolution has been largely improved through reducing sample spacing from 10 to $1 \mathrm{~cm}$.

[10] It is possible that bioturbation has reduced the quality and resolution of the downcore proxy record. However, visual inspection of the split core surfaces indicates that the influence of bioturbation is believed to be minor because both cores exhibit similar fine texture and laminations are evident in some parts of each core. In addition, the $\delta^{18} \mathrm{O}$ data derived from boxcore WLB-003C are comparable to those from the uppermost section of WLC002 both in magnitude and timing of $\delta^{18} \mathrm{O}$ response supporting the conclusion that these cores have recorded high-resolution and continuous records (Figures $2 \mathrm{~b}$ and $2 \mathrm{c}$ ).

\section{Hydrologic Variability in the Sierra Nevada}

[11] Today, Walker Lake is saline (salinity $\approx$ $12 \%)$, alkaline $(\mathrm{pH}>9)$, and monomictic

Table 2. Radiocarbon Dates From Walker Lake Core WLC002

\begin{tabular}{cccccccc}
\hline $\begin{array}{c}\text { CAMS } \\
\text { Lab } \\
\text { Number }\end{array}$ & $\begin{array}{c}\text { Section } \\
\text { Number }\end{array}$ & $\begin{array}{c}\text { Depth, } \\
\mathrm{cm}\end{array}$ & $\begin{array}{c}\text { Radiocarbon } \\
\text { Age, } \\
\text { yr BP }\end{array}$ & $\begin{array}{c}\text { Error, } \\
\pm \mathrm{yr}\end{array}$ & $\begin{array}{c}\text { Calendar } \\
\text { Age }^{\mathrm{b}} \\
\text { (AD/BC) }\end{array}$ & $\begin{array}{c}\text { Error, } \\
+\mathrm{yr}\end{array}$ & $\begin{array}{c}\text { Error, } \\
-\mathrm{yr}\end{array}$ \\
\hline 87139 & WLC002-5 & 40 & 345 & 35 & 1901 & 54 & 208 \\
87140 & WLC002-5 & 67 & 455 & 35 & 1807 & 143 & 139 \\
87141 & WLC002-4 & 86 & 645 & 35 & 1625 & 17 & 149 \\
87142 & WLC002-4 & 137 & 675 & 35 & 1495 & 140 & 48 \\
87143 & WLC002-3 & 198 & 1005 & 35 & 1290 & 100 & 27 \\
87144 & WLC002-3 & 244 & 1020 & 40 & 1285 & 103 & 42 \\
87145 & WLC002-3 & 269 & 1050 & 45 & 1265 & 111 & 45 \\
87146 & WLC002-2 & 335 & 1305 & 35 & 1025 & 133 & 43 \\
87147 & WLC002-1 & 454 & 2680 & 35 & -406 & 23 & 350 \\
\hline
\end{tabular}

${ }^{\mathrm{a}}$ Total organic carbon fraction of sediment samples was used for radiocarbon dating analyses. Samples were processed at the U.S. Geological Survey Radiocarbon Laboratory at Reston, Virginia, and dated at the Center for Accelerator Mass Spectrometry (CAMS) at Lawrence Livermore National Laboratory, Livermore, California.

${ }^{\mathrm{b}}$ Calendar ages were calibrated through the Stuiver et al. [1998] method, and a reservoir correction of 310 years was used.

${ }^{c}$ A 2- $\sigma$ error was considered. 


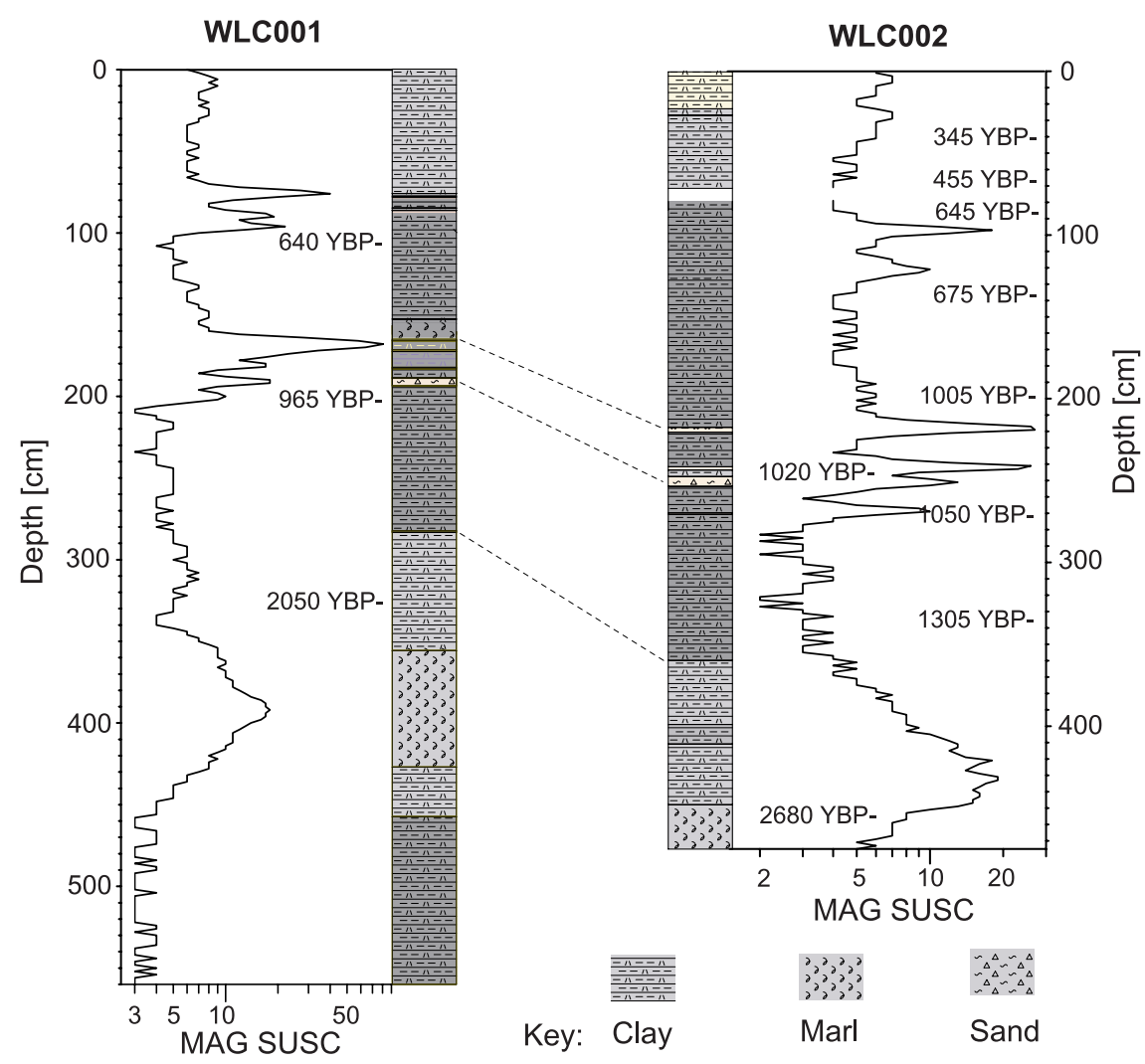

Figure 4. Stratigraphic correlations of cores WLC001 and WLC002. Dates are uncorrected radiocarbon ages measured on the TOC fraction of cored materials from cores WLC001 and WLC002. Thin bars behind the ages indicate the position of each date. Measurements of magnetic susceptibility were performed shortly after the cores were taken.

[Cooper and Koch, 1984; Beutel et al., 2001]. Surface water temperature ranges from $6.0^{\circ} \mathrm{C}$ in winter to $22.5^{\circ} \mathrm{C}$ in summer with an annual mean temperature of $14.5^{\circ} \mathrm{C}$, while bottom water temperature ranges from $6.0^{\circ} \mathrm{C}$ in winter to $9.5^{\circ} \mathrm{C}$ in summer [Benson and Spencer, 1983; Cooper and Koch, 1984]. Typically, lake overturn takes place after December and lasts until April or early May [Koch et al., 1979; Benson and Paillet, 2002]. The bulk of $\mathrm{CaCO}_{3}$ precipitation occurs when the top mixed layer reaches its highest temperatures in August or September [Galat and Jacobson, 1985]. The $\delta^{18} \mathrm{O}$ signatures preserved in downcore carbonate sediments usually mirror variations in $\delta^{18} \mathrm{O}$ of the mixed layer, which is a function of three components: the amount and $\delta^{18} \mathrm{O}$ of inflow, evaporation, and lake-surface waters derived from the fully mixed lake. Over the past 100 years, Walker Lake elevation has declined rapidly due to a substantial reduction $(\sim 60 \%)$ of river inflow resulting from increasing irrigation demands and impoundments of upstream reaches [Benson and Leach, 1979]. Flow reduction has become a dominant factor in affecting the $\delta^{18} \mathrm{O}$ value of the mixed layer. The TIC $\delta^{18} \mathrm{O}$ derived from downcore sediments effectively parallels the anthropogenic lake-level lowering (Figure 2). The anthropogenically induced drought is recorded in downcore sediments as a $6 \%$ increase in TIC $\delta^{18} \mathrm{O}$. During the El Niño years of $1982-83$ and 1997-98, Walker Lake (like Pyramid Lake) received well above average moisture. The lake volume increased by $28 \%$ from its September 1981 value and the $\delta^{18} \mathrm{O}_{\mathrm{L}}$ decreased 3.6\%o during the 1982-83 event [Benson et al., 1991]. This climate-induced wet event was well recorded in downcore sediments as a $\sim 3 \%$ decrease in TIC $\delta^{18} \mathrm{O}$ (Figures $2 \mathrm{~b}$ and $2 \mathrm{c}$ ). The El Niño event of 1997-98 was also recorded in box core WLB003C as a $\sim 2 \%$ decrease in TIC $\delta^{18} \mathrm{O}$ 


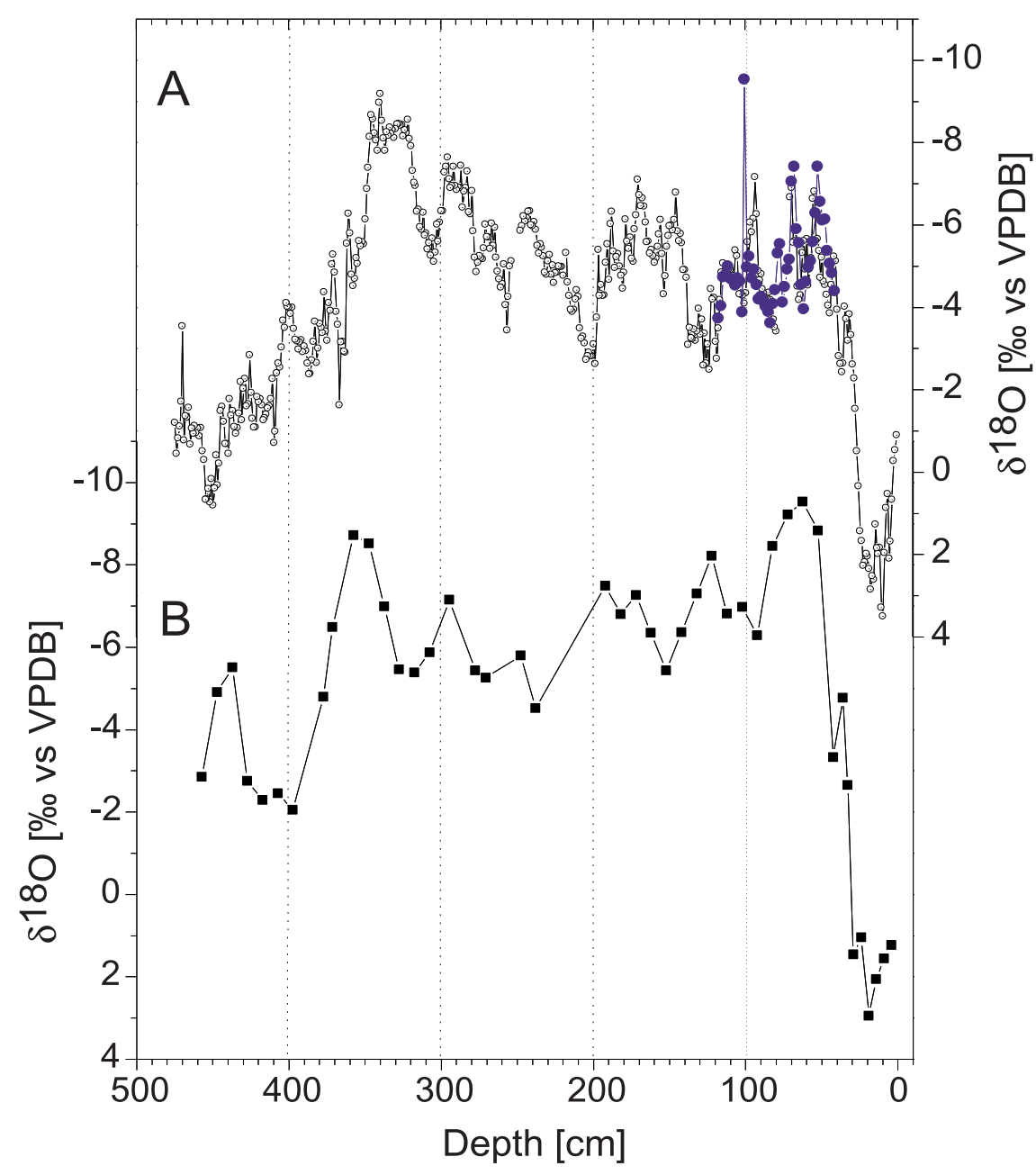

Figure 5. (a) Raw $\delta^{18} \mathrm{O}$ results derived from core WLC001 (blue solid dots) and WLC002 (open circles). (b) Results of $\delta^{18} \mathrm{O}$ measurements from core WLC84-8 with a sample spacing of approximate $10 \mathrm{~cm}$ [Benson et al., 1991].

(Figure 2c). The relatively large shift in the $\delta^{18} \mathrm{O}$ values in the latest 20th century was due to the relatively small lake volume [Benson et al., 1996].

[12] To evaluate pre-anthropogenically influenced changes in basin hydrology prior to the construction of surface impoundments in the early 20th century, in Figure 6 we focus on the record from AD 800 to 1900 . Over this interval the \%TIC record from core WLC002 is generally correlative to the TIC $\delta^{18} \mathrm{O}$ record $(r=0.57, \mathrm{~N}=390)$ (Figures $6 \mathrm{a}$ and $6 \mathrm{~b}$ ). In Figure $6 \mathrm{~b}$ the \% $\%$ TIC record has been smoothed with a 5 point moving average. This correspondence suggests that both TIC and TIC $\delta^{18} \mathrm{O}$ are affected by similar mechanisms [Benson et al., 2002]. For example, more $\mathrm{CaCO}_{3}$ tends to precipitate in the lake during times when there is a more positive $\delta^{18} \mathrm{O}$ signature in the dissolved inorganic carbon (DIC) and when the hydrologic budget of the lake is more negative. The higher frequency variability of the TIC data is likely related to carbonate chemistry (e.g., availability of $\mathrm{Ca}$ ) and other biogeochemical processes. The time series of TIC $\delta^{18} \mathrm{O}$ displays 2 to 4 per mil century scale variations prior to AD 1900 while TIC varies about $4 \%$ (Figures $6 \mathrm{a}$ and $6 \mathrm{~b}$ ). On interdecadal to century timescales, there are approximately 13 dry periods that on the basis of our age model end in AD 870, $1060,1140,1210,1280,1360,1480,1560,1620$, $1670,1730,1790$, and 1840 . The $\delta^{18} \mathrm{O}$ results indicate that the lake may have received a substantial 


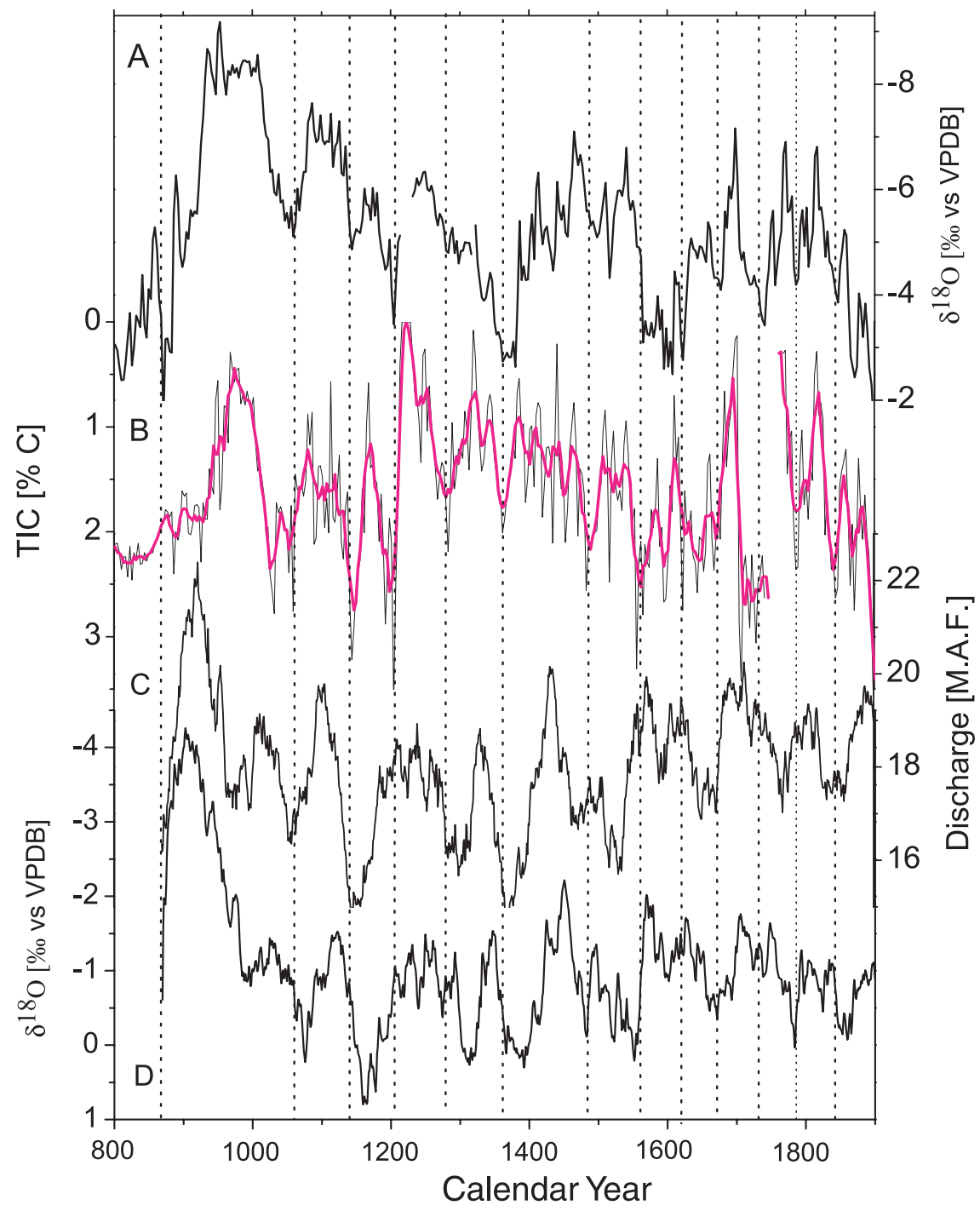

Figure 6. (a) Time series of bulk inorganic carbonate $\delta^{18} \mathrm{O}$ spliced from WLC001 and WLC002. (b) Percent TIC results derived from WLC002. Thick pink curve is 5-point adjacent averaging smoothing of the raw TIC data to emphasize low frequency variability. (c) Smoothed discharge record of the Sacramento River through 40-point adjacent averaging [Meko et al., 2001]. (d) Model-derived water $\delta^{18} \mathrm{O}$ results of Walker Lake through the hydrologicisotopic balance model (HIBAL) [Benson and Paillet, 2002] using scaled annual discharge data of the Sacramento River [Meko et al., 2001]. Model parameters like precipitation, evaporation, temperature, relative humidity, and wind speed were determined through instrumental-based weather data in this region [Benson and Paillet, 2002]. Vertical dashed lines denote possible trough-to-trough correlations between these records.

amount of fresh water at the beginning of the record because the sediment record displays a large decrease (6-7\%) in TIC $\delta^{18} \mathrm{O}$ from AD 800 through 1000. After this wet interval, TIC $\delta^{18} \mathrm{O}$ increased progressively in century-scale steps to a maximum $\delta^{18} \mathrm{O}$ value in $\mathrm{AD} 1360$. The trend of progressive increases in $\delta^{18} \mathrm{O}$ is interpreted to reflect overall long-term negative water budget, indicating dry conditions prevailing at least basin-wide during the period of AD 1000 to 1360 . Though the sediments were relatively ${ }^{18} \mathrm{O}$-depleted in this interval, this does not necessarily imply that the lake was in a relatively highstand as the $\delta^{18} \mathrm{O}$ value depends on the rate of lake-volume change and cannot be used as a simple index of the exact volume of the lake [Benson et al., 1991]. For example, the $\delta^{18} \mathrm{O}$ values of the latest 20 th century are about $-4 \%$ that is close to those of pre-1900s, whereas their concurrent lake 
volumes are substantially different. Alternations between relatively dry and relatively wet climate became more frequent after AD 1360. Peak to peak comparison of the tree ring-based Sacramento River (TSR) flow and the Walker Lake $\delta^{18} \mathrm{O}$ indicates that many of the droughts on the eastern and western flanks of the Sierra Nevada occurred at similar times (Figure 6c). A long-term trend of decreasing TSR discharge is also noticeable in the interval from AD 950-1360 (Figure 6c). To attempt to further understand the past changes in regional hydrology a simulated $\delta^{18} \mathrm{O}_{\mathrm{L}}$ record was generated through a hydrologic-isotopic balance model (HIBAL) [Benson and Paillet, 2002]) using scaled annual TSR discharge data [Meko et al., 2001] (Figure 6d). This modelderived $\delta^{18} \mathrm{O}_{\mathrm{L}}$ also shows close similarity with the TIC $\delta^{18} \mathrm{O}$ record. This suggests that the Walker Lake $\delta^{18} \mathrm{O}$ record likely contains a regional signal of changes in Sierra Nevada wetness even though there exist timing discrepancies that are likely the result of age-model uncertainty in the Walker Lake record.

[13] It has also been proposed that the past elevation of Walker Lake may have been influenced by possible upstream diversion of the Walker River through Adrian Valley [King, 1978]. In this case, the TIC $\delta^{18} \mathrm{O}$ signal from Walker Lake may not completely reflect regional climate changes. To examine the possibility for past diversions we compared our record with a TIC $\delta^{18} \mathrm{O}$ record from Pyramid Lake (Figure 7b) and found that both records were comparable on century timescales. The average $\delta^{18} \mathrm{O}$ value of Pyramid Lake TIC is less negative, and the magnitude of $\delta^{18} \mathrm{O}$ variations are relatively smaller compared to the Walker Lake record. This is in part because the size/volume of Pyramid Lake is larger than that of Walker Lake. In this sense, Walker Lake may be more sensitive to basin-wide climate changes. The similar timing of many $\delta^{18} \mathrm{O}$ changes in these two records suggests that the diversion of the Walker River through Adrian Pass apparently did not occur during the last 1200 years. In addition, analysis of diatom flora from Walker Lake showed a gradual declining trend in diatom concentration which was apparently inconsistent with proposed diversion scenarios over the last few thousand years [Bradbury, 1987]. The overall similarity of the Walker Lake TIC $\delta^{18} \mathrm{O}$ and the TSR records also suggests that Walker River diversions did not occur during the last millennium.

[14] To address the spatial scales of hydrologic oscillations in the last millennium, we compare the lake-based results with other proxy records from the western U.S.; San Francisco Bay (SFB) salinity [Ingram et al., 1996], northwestern New Mexico precipitation [Grissino-Mayer, 1996], and precipitation in the White Mountains of eastern California [Hughes and Graumlich, 1996] (Figure 7). All data presented in Figure 7 are smoothed results using a bidecadal Gaussian filter to emphasize multidecadal to century scale variability. The inferred SFB salinity is an indicator of stream discharge from the Sacramento and San Joaquin Rivers that receive rain and snowmelt mainly from the Sierra Nevada [Ingram et al., 1996]. Despite the limitations in each proxy record, there exist several peak-to-peak correlations between the SFB salinity data and the lake-based $\delta^{18} \mathrm{O}$ results, which can be ascribed to the same water sources in the Sierra Nevada. The tree ring based precipitation reconstructions also documented a number of multidecadal droughts. Most droughts coincide with lake-level lowering in Walker and Pyramid Lakes and when salinity was increasing in SFB. In the Sierra Nevada, Stine [1994] found strong evidence for substantial multicentury droughts that occurred between AD 9001100 and $\mathrm{AD} 1350-1200$ and termed the period the Medieval Climatic Anomaly (MCA). As highlighted in Figure 7, Walker Lake and SFB received relatively less moisture during the two periods within the MCA. In addition, the Walker Lake $\delta^{18} \mathrm{O}$ record indicates another drought occurred in the interval between AD 900-1100 and $\mathrm{AD} 1350-1200$.

\section{Comparison to the Santa Barbara Basin Record of Water Temperature and to Indirect Indices of Solar Variability}

[15] To evaluate the larger-scale significance of the two sediment-based Sierran wetness records (Figures 8a and 8b), we compared them with a 


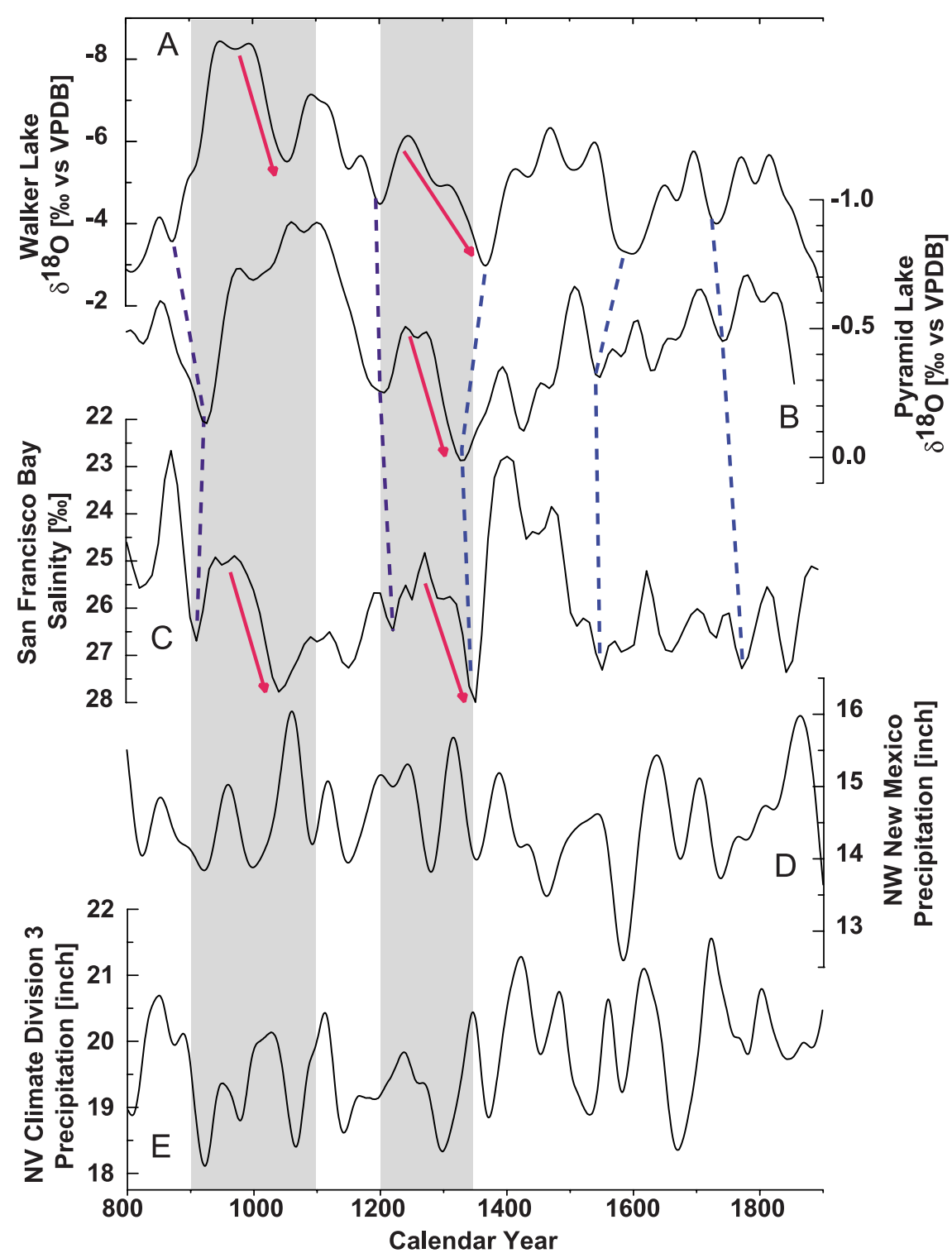

Figure 7. Comparison of smoothed records of (a) Walker Lake $\delta^{18} \mathrm{O}$, (b) Pyramid Lake $\delta^{18} \mathrm{O}$ [Benson et al., 2002], (c) San Francisco Bay Salinity [Ingram et al., 1996], (d) Northwestern New Mexico precipitation [Grissino-Mayer, 1996], (e) Nevada Climate Division 3 precipitation [Hughes and Graumlich, 1996]. Smoothing was done using a bidecadal Gaussian filter to emphasize low-frequency variability. Two shaded columns indicate the timing of multicentury-scale droughts identified from killed tree stumps rooted in the West Walker River by Stine [1994]. Nearly vertical dashed lines denote possible connections of the $\delta^{18} \mathrm{O}$ records of Walker and Pyramid Lakes with the salinity record of San Francisco Bay. Red arrows highlight substantial lake-level lowering events in Walker and Pyramid Lakes or reduced discharge events in San Francisco Bay during the Medieval Warm Epoch.

$\delta^{18} \mathrm{O}$ record derived from planktonic foraminfera in the Santa Barbara Basin (SBB) (Figure 8d) [Field and Baumgartner, 2000] and to a cosmogenic nuclide production record derived from ${ }^{10} \mathrm{Be}$ measurements of South Pole ice cores (Figure 8c) [Raisbeck et al., 1990; Bard et al., 2000]. The SBB $\delta^{18} \mathrm{O}$ record was interpreted to indicate changes in sea temperatures within the upper thermocline [Field and Baumgartner, 2000]. Changes in SBB sea surface temperatures (SST) are known to be related to changes in the California Current and regional coastal upwelling system. Today, the Cal- 

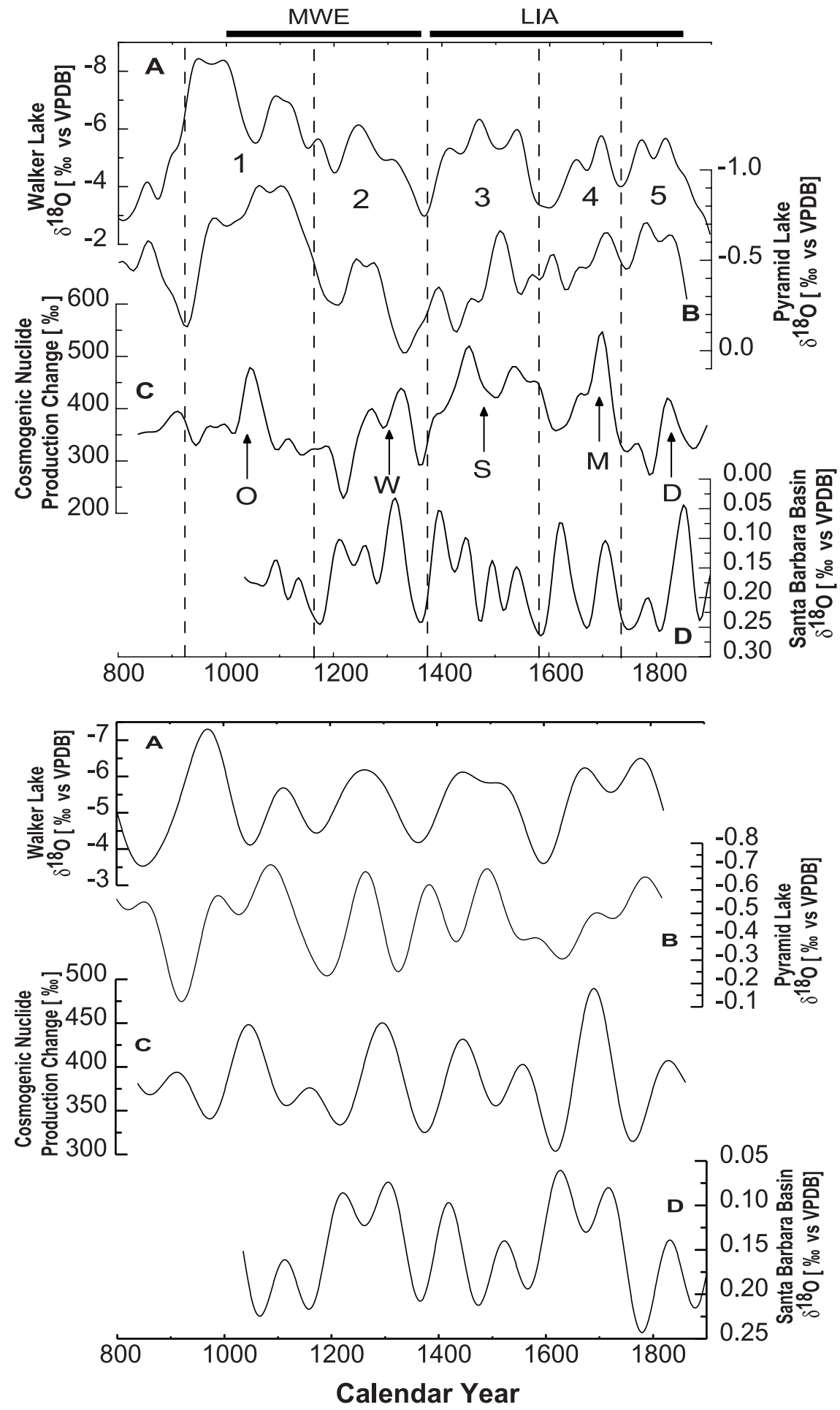

Figure 8. Upper panel: raw data were smoothed using a bidecadal Gaussian filter. (a) The same data as in Figure 7a. (b) The same data as in Figure 7b. (c) Smoothed time series of the cosmogenic nuclide production changes derived from the ${ }^{10} \mathrm{Be}$ concentrations in South Pole ice [Raisbeck et al., 1990; Bard et al., 2000]. (d) N. dutertrei $\delta^{18} \mathrm{O}$ results of Santa Barbara Basin [Field and Baumgartner, 2000]. Vertical dashed lines denote possible correlations between these proxy records. MWE: Medieval Warm Epoch, AD 1000 to 1350. LIA: Little Ice Age, AD 1350 to 1850. Numbers 1 to 5 designate five major century-scale wet events that may be indirectly related to five minima of solar activity: O-Oort (AD 1010-1050), W-Wolf (AD 1280-1340), S-Spörer (AD 1420-1530), M-Maunder (AD 16451715), D-Dalton (AD 1810) [Bard et al., 2000]. Lower panel: multicentury components were extracted through a multicentury (100 to $500 \mathrm{yr}$ ) bandpass filter. 
ifornia Current weakens and retracts to the north during most El Niño years, and coastal upwelling diminishes [Simpson, 1983] and SSTs increase along the California margin. Within the errors of each age model changes in SBB $\delta^{18} \mathrm{O}$ and the Sierran wetness from Walker and Pyramid Lakes in several intervals may correlate. Such a correlation would imply that there exists some degree of linkage of marine climate to land moisture variability in these regions. In fact, this marine to land climate connection has been previously identified on interannual [Ely et al., 1994], interdecadal [Benson et al., 2003] and glacial-interglacial [Herbert et al., 2001] timescales.

[16] The cosmogenic nuclide production record shown in Figure 8c has been interpreted to reflect changes in solar activity [Bard et al., 2000]. We note that on century timescales, the Sierran wetness records can be separated into five major oscillations numbered 1 to 5 (see Figure 8) that are nearly concurrent with five major oscillations in solar activity tagged O-Oort (AD 1010-1050), W-Wolf (AD 1280-1340), S-Spörer (AD 14201530), M-Maunder (AD 1645-1715), and D-Dalton (AD 1810). However, the exact linkage between solar activity and earth's climate remains poorly understood and changes in solar irradiance may not be directly and immediately reflected in coastal SSTs because of the complex nature in this system.

[17] Today, the Sierra moisture conditions are primarily determined by wintertime precipitation that is closely linked to the position of the atmospheric jet stream. The unusual dry climate in the MWE was previously attributed to a contraction of the circumpolar vortex that resulted in the atmospheric jet stream remaining to the north of California throughout much of the MWE [Stine, 1994]. Our results support this hypothesis. In addition, although only suggestive in our data, if future improvements in our Walker Lake sediment chronology can definitively link changes in Walker Lake hydrologic balance to changes in solar irradiance, this would indicate that past changes in solar irradiance played an important role in modulating century-scale variability in jet stream position, regional coastal wind stress and upwelling, and moisture balance in the Sierra Nevada.

\section{Acknowledgments}

[18] We are indebted to L. Benson for his supervision of core collection, thoughtful ideas and discussions, and reviews of an early version of this manuscript. We also thank J. Smoot, A. Heyvaert and B. Richards for field assistance in core collection, and D. Rodbell and S. Howe for analytical assistance. The radiocarbon analyses were kindly supported through J. Rosenbaum's program at the U.S. Geological Survey. The first author wishes to thank the support of the University at Albany-State University of New York and the U.S. Geological Survey. Finally, we acknowledge P. deMenocal and an anonymous reviewer for their valuable comments and suggestions.

\section{References}

Bard, E., G. Raisbeck, F. Yiou, and J. Jouzel (2000), Solar irradiance during the last 1200 years based on cosmogenic nuclides, Tellus, Ser. B, 52(3), 985-992.

Benson, L. (1988), Preliminary paleolimnological data for the Walker Lake Subbasin, California and Nevada, U.S. Geol. Surv. Water Resour. Invest. Rep., 87-4258, pp. 50.

Benson, L. V., and D. L. Leach (1979), Uranium transport in the Walker River Basin, California and Nevada, J. Geochem. Explor, 11(3), 227-248.

Benson, L., and F. Paillet (2002), HIBAL: A hydrologic-isotopic-balance model for application to paleolake systems Quat. Sci. Rev., 21(12-13), 1521-1539.

Benson, L. V., and R. J. Spencer (1983), A hydrochemical reconnaissance study of the Walker River Basin, California and Nevada, U.S. Geol. Surv. Open File Rep., 83-740, 53 pp.

Benson, L. V., and J. W. C. White (1994), Stable isotopes of oxygen and hydrogen in the Truckee River-Pyramid Lake surface-water system. 3. Source of water vapor overlying Pyramid Lake, Limnol. Oceanogr., 39(8), 1945-1958.

Benson, L. V., P. A. Meyers, and R. J. Spencer (1991), Change in the size of Walker Lake during the past 5000 years, Palaeogeogr. Palaeoclimatol. Palaeoecol., 81(3-4), 189214.

Benson, L., L. D. White, and R. Rye (1996), Carbonate deposition, Pyramid Lake Subbasin, Nevada: 4. Comparison of the stable isotope values of carbonate deposits (tufas) and the Lahontan lake-level record, Palaeogeogr. Palaeoclimatol. Palaeoecol., 122(1-4), 45-76.

Benson, L., S. Lund, F. Paillet, J. Smoot, C. Kester, S. Mensing, D. Meko, S. Lindström, M. Kashgarian, and R. Rye (2002), Holocene multidecadal and multicentennial droughts affecting northern California and Nevada, Quat. Sci. Rev., 21(4-6), 659-682.

Benson, L., B. Linsley, J. Smoot, S. Mensing, S. Lund, S. Stine, and A. Sarna-Wojcicki (2003), Influence of the Pacific decadal oscillation on the climate of the Sierra Nevada, California and Nevada, Quat. Res., 59(2), 151-159. 
Beutel, M. W., A. J. Horne, J. C. Roth, and N. J. Barratt (2001), Limnological effects of anthropogenic desiccation of a large, saline lake, Walker Lake, Nevada, Hydrobiologia, 466, 91-105.

Bradbury, J. P. (1987), Late Holocene diatom paleolimnology of Walker Lake, Nevada, Arch. Hydrobiol. Suppl., 79(1), $1-$ 27.

Bradley, R. S. (2000), Climate paradigms for the last millennium, CLIVAR Exchanges, 5(1), 2-3.

Broecker, W. S., and A. Walton (1959), The geochemistry of $\mathrm{C}^{14}$ in fresh-water system, Geochim. Cosmochim. Acta, 16, $15-38$.

Cobb, K. M., D. C. Christopher, H. Cheng, and R. L. Edwards (2003), El Niño/Southern Oscillation and tropical Pacific climate during the last millennium, Nature, 424, 271-276.

Cooper, J. J., and D. L. Koch (1984), Limnology of a desertic terminal lake, Walker Lake, Nevada, USA, Hydrobiologia, $118,275-292$.

Crowley, T. J. (2000), Causes of climate change over the past 1000 years, Science, 289(5477), 270-277.

Ely, L. L., Y. Enzel, and D. R. Cayan (1994), Anomalous North Pacific atmospheric circulation and large winter floods in the southwestern United States, J. Clim., 7(6), 977-987.

Field, D. B., and T. R. Baumgartner (2000), A 900 year stable isotope record of interdecadal and centennial change from the California Current, Paleoceanography, 15(6), 695-708.

Galat, D. L., and R. L. Jacobson (1985), Recurrent aragonite precipitation in saline-alkaline Pyramid Lake, Nevada, Arch. Hydrobiol., 105, 137-159.

Grissino-Mayer, H. D. (1996), A 2129-year reconstruction of precipitation for northwestern New Mexico, USA, in Tree Rings, Environment, and Humanity, edited by T. W. Swetnam, pp. 191-204, Radiocarbon, Tucson, Ariz.

Herbert, T. D., J. D. Schuffert, D. Andreasen, L. Heusser, M. Lyle, A. C. Ravelo, L. D. Stott, and J. C. Herguera (2001), Collapse of the California Current during glacial maxima linked to change on land, Science, 293, 71-76.

Hughes, M. K., and L. J. Graumlich (1996), Multimillennial dendroclimatic studies from the western United States, in Climatic Variations and Forcing Mechanisms of the Last 2000 Years, edited by J. Jouzel, pp. 109-124, SpringerVerlag, New York.

Ingram, B. L., J. C. Ingle, and M. E. Conrad (1996), Stable isotope record of late Holocene salinity and river discharge in San Francisco Bay, California, Earth Planet. Sci. Lett., 141(1-4), 237-247.
Jones, P. D., T. J. Osborn, and K. R. Briffa (2001), The evolution of climate over the last millennium, Science, 292(5517), $662-667$.

King, G. Q. (1978), The late Quaternary history of Adrian Valley, Lyon County, Nevada, thesis, Univ. of Utah, Salt Lake City.

Koch, D. L., J. J. Cooper, E. L. Lider, R. L. Jacobson, and R. J. Spencer (1979), Investigations of Walker Lake, Nevada: Dynamic ecological relationships, internal report, Univ. of Nev., Reno.

Meko, D. M., M. D. Therrell, C. H. Baisan, and M. K. Hughes (2001), Sacramento river flow reconstructed to A.D. 869 from tree rings, J. Am. Water Resour. Assoc., 37(4), 1029-1038.

Milne, W., and L. V. Benson (1987), A comparison of reconstructed lake-level records since the mid-1800's of some Great Basin lakes, Eos Trans. AGU, 68(44), 1274.

Raisbeck, G., F. Yiou, J. Jouzel, and J.-R. Petit (1990), ${ }^{10}$ Be and ${ }^{2} \mathrm{H}$ in polar ice cores as a probe of the solar variability's influence on climate, Philos. Trans. R. Soc. London, Ser. A, 300, 463-470.

Redmond, K. T., and R. W. Koch (1991), Surface climate and streamflow variability in the western United States and their relationship to large-scale circulation indices, Water Resour. Res., 27(9), 2381-2399.

Scuderi, L. A. (1993), A 2000-yr tree ring record of annual temperatures in the Sierra Nevada Mountains, Science, 259(5100), 1433-1436.

Simpson, J. J. (1983), Large-scale thermal anomalies in the California Current during the 1982-1983 El Nino, Geophys. Res. Lett., 10(10), 937-940.

Smith, G. H. (1943), The History of the Comstock Lode 18501920, 297 pp., Nev. State Bur. of Mines and the Mackay School of Mines, Reno.

Spencer, R. J. (1977), Silicate and carbonate sediment-water relations in Walker Lake, Nevada, 97 pp., thesis, Univ. of Nev., Reno.

Stine, S. (1994), Extreme and persistent drought in California and Patagonia during mediaeval time, Nature, 369(6481), 546-549.

Stuiver, M., P. J. Reimer, and T. F. Braziunas (1998), Highprecision radiocarbon age calibration for terrestrial and marine samples, Radiocarbon, 40(3), 1127-1151.

Ware, D. M., and R. E. Thomson (2000), Interannual to multidecadal timescale climate variations in the northeast Pacific, J. Clim., 13(18), 3209-3220.

Yuan, F. (2003), Late Holocene hydrologic and climatic variability in the Walker Lake Basin, Nevada and California, Ph.D. thesis, Univ. at Albany, Albany, New York. 